\title{
Climate-Change Migration in the Pacific
}

John R Campbell

\begin{abstract}
T here is considerable debate about the links between environmental change (particularly degradation) and migration. This is no more so than in the case of climate change and population mobility. While the distinction is not a cut and dried one, there tends to be a division between two schools of thought. First, some working in the area of climate-change impacts foresee large numbers of people being forced to move as a result of rising sea levels, increases in the magnitude and/or frequency of climate-related extreme events, and other forms of environmental degradation caused by global warming. These observers, who tend to see migration in a negative light, have estimated that very large numbers of people globally will become "environmental refugees" or be displaced by the effects of climate change. For example, Norman Myers's suggestion that there may be as many as two hundred million environmental refugees by the time "global warming takes hold" (perhaps around mid-twenty-first century) has gained considerable acceptance (Myers 2005). Several environmental organizations and a number of aid groups consider that the numbers of environmental migrants may well exceed Myers's estimates; for example, Christian Aid has suggested that the number of people displaced by climate change may exceed one billion (2007).

In comparison, many social scientists, particularly migration scholars, are loath to attribute a significant role to environmental drivers of migration decision making and in any case see migration as a positive outcome (Barnett and Webber 2010; Tacoli 2009). One of the major arguments is that there is little empirical evidence to support claims of very large migration flows resulting from climate change. The problem is that there cannot possibly be much empirical evidence to support arguments for
\end{abstract}

The Contemporary Pacific, Volume 26, Number I, I-28

(C) 2014 by University of Hawai'i Press 
or against climate-change migration (as opposed to climate migration) either because it is only just at its onset (see, eg, Warner and others 2009) or has yet to begin (at least in significant numbers) or because we cannot attribute to climate change any individual climatic events that might currently be leading to migration. Most research is based on historical analogues, which are usually responses to extreme events and based on relatively stable long-term baseline environmental conditions that eventually return to some kind of "norm," enabling return migration and reestablishment of communities. This is not likely to be the case with climate change, which largely includes variability around a changing mean, or increasing magnitude and/or frequency of extremes, through time. Returns to "normalcy" enabling return migration may simply not happen, or they may become fewer and further between. We have very few if any analogues for such conditions. Oli Brown examined different Intergovernmental Panel on Climate Change (IPCC) scenarios and distinguished between an increase of between 5 and Io percent in migration along existing pathways under the least disruptive scenario (BI) to the displacement of over two hundred million people under the worst scenario (AIFI-an intensive fossil fuel-based future) (Brown 2008). To date, other than pointing out that climate change may bring about changes in migration, the IPCC itself has not sought to quantify the likely numbers. ${ }^{1}$

Much of the work on climate change and migration has tended to emanate from Europe and, to a lesser extent, North America, and most authors take a pro-migration stance, perhaps partly as a response to xenophobic popular and political views of migration and fears of being "swamped" by climate-change refugees. Moreover, much of their work has focused on sub-Saharan Africa and South Asia, with very little reference to small islands. Despite this, many popular and political discussions of climatechange migration refer to small islands and atolls as being likely origins of displaced persons, and Pacific Island Countries and Territories (PICTs) are often identified as being among the most vulnerable to the effects of climate change and the origin of the "first climate change refugees" (see, eg, Morton 2009). Despite this, relatively little research has been done on the possible migration processes for PICTs that may be initiated by climate change, let alone their likely outcomes. Notwithstanding the large uncertainties, particularly in the ways that climate change might be manifested, in this article I canvass the possible migration and relocation outcomes of climate change in PICTs. 


\section{Climate Change in Pacific Island Countries AND Territories: EFFECTS AND Responses}

The processes of climate change and their effects in the region are likely to have serious implications for PICTs, and communities and governments will have to find ways of responding to them. Climate-change projections for PICTs are compromised by the small size of islands in relation to the coarse grids used in the models common in climate-change research. The IPCC, in its Fourth Assessment Report (Mimura and others 2007), indicated that freshwater supplies of small islands are likely to be stressed by increased exposure to droughts, a possible increase in tropical cyclone intensity, increases in the severity and frequency of intense rainfall events, and problems associated with sea-level rise. A more recent study has been conducted as part of the Pacific Climate Change Science Program (ABM and CSIRO 2OII). This study, unlike the IPCC, suggests that drought events may not be so frequent and that tropical cyclones may become less frequent. It points to increasing ocean acidification and sea-level rise (projected to rise by around eighty centimeters by $2 \mathrm{IOO}$ ) as having serious implications for coastal ecosystems. Considerable uncertainty remains about the physical manifestations of climate change in Oceania. Generally, five main areas have been identified in which the effects of climate change may have serious implications: (I) coastal effects of sea-level rise (including erosion and inundation); (2) reduced quantity or quality of water resources; (3) coral reef degradation; (4) reduced agricultural productivity; and (5) impacts on human health (eg, changing disease vectors, heat-related diseases, and water-borne diseases).

It is also important to take into account the considerable variability in the physical environments of Pacific Islands. Large islands built along the boundaries between oceanic and continental tectonic plates in the western Pacific, often referred to as "continental" or plate-boundary islands, have high elevations, well-developed hydrological systems, and relatively high levels of biodiversity. Islands lying to the east of the plate boundaries are referred to as oceanic islands. These include volcanic high islands, built over "hot spots" in the earth's mantle, which exist in various states, subsiding as they move away from the hot spots through the movement of the oceanic plate and through erosion as they are exposed to the elements over time. These islands are characterized by porous soils, poorly developed river systems, and fringing and barrier reefs. Atolls are islands 
built on coral reefs that have grown on submerged volcanic high islands. Typically, they are extremely low lying, usually only a few meters above sea level, with no soils, no surface water, very low levels of terrestrial biodiversity, and relatively fragile groundwater systems. Some atolls have become stranded above sea level and are often referred to as raised limestone islands. Considerable variation also exists within each of these categories. Accordingly, the effects of climate change are likely to be variable across the region.

Two broad categories of human responses to climate change are now used in most climate-change discourse: mitigation and adaptation..$^{2}$ Mitigation refers to activities that seek to reduce the emissions of greenhouse gases (GHGS) into the troposphere. PICTs generally have very low rates of GHG emissions (Barnett and Campbell 2010), even on a per capita basis, and can do little themselves to slow down the rates of increasing concentrations of tropospheric greenhouse gases. There are, however, regional programs to promote renewable energy (SPC 2OIO; SPREP 2OI2), and some countries are establishing policies to reduce emissions related to deforestation (see, eg, Fiji Forestry Department 20II). From the PICT perspective, their most important weapon for reducing GHG emissions is moral suasion, which to date has had little political leverage despite the efforts of the countries themselves and of the Alliance of Small Island States (AOSIS), an international umbrella organization. The weak commitments included in the Kyoto Protocol and the failure of developed countries to meet even these and to reach agreement on a second commitment period indicate a considerable lack of political will among a number of heavy greenhouse gas emitters.

Given the inability of the international regime to significantly reduce greenhouse gas concentrations, adaptation has become an increasingly urgent response option. Generally, adaptation refers to measures that enable communities to cope with, and where possible benefit from, the effects of global warming. ${ }^{3}$ In the Pacific region, the benefits are difficult to project, but there are likely to be a considerable number of adverse effects on the security of PICT communities. The effects of climate change are likely to influence island environments as sites of human settlement (their "life-support systems") in three ways. First, some of these effects may have impacts on land security, which is the physical presence of land on which to live and sustain livelihoods. Second, they may impinge on the livelihood security (especially food security) of island communities where the productivity of subsistence and commercial activities may be reduced; in extreme cases, the loss of productivity may be severe. Third, the effects of climate 
change on small-island environments may result in declining habitat security, in which, despite the existence of land and livelihoods, other factors such as declining health bring about reductions in community well-being. Table I shows the five sets of climate-change effects on islands, together with their implications for land, livelihood, and habitat security.

Table I. The Main Effects of Climate Change on PICTs and Implications for Community Security

Main Effects Implications

Sea-Level Rise:

- inundation

- coastal erosion

- storm surge exacerbated

Water Resources:

- rainfall uncertainty

- increased frequency and magnitude of droughts

- reduced quantity and quality of water resources

- salinization

Coral Reefs:

- reef degradation as a result of increased sea surface temperatures and increased ocean acidity

Agriculture:

- adverse effects from a variety of processes including temperature rise, reduced water availability, salinization, and exposure to tropical cyclones (wind, rain, and wave damage)

Human Health:

- changing disease vectors such as malaria and dengue

- increased incidence of waterborne diseases

- increased incidence of heatrelated diseases
Land security in coastal and atoll locations may be severely reduced and there may be impacts on livelihood security through loss of agricultural land and salinization of soils, plants, and water supplies.

Livelihood security may be affected by decreased agricultural productivity and habitat security may be adversely affected by water borne diseases.

Livelihood security may be compromised by reductions in fisheries and other marine resources dependent on healthy coral environments. Land security may be reduced by increased exposure to high waves and storm surges.

Reduced agricultural productivity would impinge on livelihood security and, where extremely severe, may render some locations uninhabitable (habitat security).

Effects on human health are likely to reduce the habitat security of island settlement locations and, where severe, may render some locations uninhabitable.

Source: After Campbell and Bedford 2013. 
Where are these effects on island life-support systems most likely to be manifested? First, some atoll communities may lose land security through erosion and inundation and may lose livelihood and habitat security as a result of reduced quantity and quality of water supplies and loss of food production. Key concerns here are the rate and magnitude of sea-level rise and changes in drought occurrence, intensity, and duration. Atolls in tropical cyclone-prone areas may experience events of greater intensity in the future. Second, coastal locations may similarly become uninhabitable. With the exception of some of the larger Melanesian islands, the great majority of settlements in the region, including all but a few towns and cities, are near sea level. There are already many examples of communities relocating following repeated or major tropical cyclones, and this trend may increase if climate scenarios of sea-level rise and tropical cyclone intensity eventuate (Campbell and others 2007). Third, communities located in river deltas may be particularly prone to river flooding and sea-level rise, which may lead to the erosion and/or inundation of settlements and agricultural land. Deltas may be affected by sea-level rise, and when there is river flooding and storm surge, they are likely to be especially at risk. River deltas are mostly found in the larger Melanesian islands, with their well-developed river systems, and such areas are often densely populated. Fourth, there may also be inland river communitiesagain mostly on the larger inter-plate or continental-type islands common to the western Pacific - the members of which may be placed at greater risk from flood events, especially, as is common, where villages are located next to waterways. Finally, some areas may become increasingly affected by droughts of high magnitude, such as those that are often experienced during El Niño events in the western part of the region, including the Papua New Guinea Highlands, one of the most densely populated regions of that country.

Adaptation includes measures that are implemented locally (in situ) to enable continued occupancy of a place, and a number of such measures could be implemented at relatively little cost and with benefits irrespective of climate change. These include improving public health, disaster risk reduction, and water supply systems; promoting coral reef and marine conservation; and developing measures to reduce impacts on crops. However, there may be instances in which these may be inadequate, impracticable, or too difficult to realize, and movement to locations that are able to provide greater security is a likely outcome. But migration need not always be considered as an alternative to in situ adaptation or as a 
measure of last resort; it can also be seen as part of an integrated adaptation strategy (Barnett and Webber 2010). Nevertheless, in some extreme circumstances it is likely to be the only option left when the life-support systems (land, livelihood, and/or habitat security) of a community's territory fail. In such cases, the migration becomes forced, and the movement may involve whole or large portions of communities.

\section{ISLAND VULNERABILITIES}

It is important here to include a brief observation about the resilience of communities in Pacific Island Countries and Territories. Along with other Small Island Developing States (SIDS), PICTs have been identified in numerous international forums and treaties as being particularly vulnerable to climate change. This is mostly based on notions that islands are inherently vulnerable (economically and environmentally) and that sea-level rise in particular, together with increasing magnitude and/or frequency of climatic extremes, will render uninhabitable a number of locations that currently support populations. However, considerable evidence suggests that Pacific Islands people are highly resilient and not somehow inherently vulnerable (Bayliss-Smith and others I988; Barnett and Campbell 2010). Furthermore, the effects of climate change remain uncertain. In addition to the uncertainty regarding what will happen to existing PICT communities, the question remains of when the effects of climate change are likely to be manifested in ways that require some form of adaptive response. Moreover, people from PICTs are highly mobile, and migration is a key existing characteristic of PICT societies and plays a fundamental role in their development (Barnett and Chamberlain 2010). Any discussion of climate change and migration must take these considerations into account.

\section{Pacific Island Countries and Territories: Environmental and Demographic Futures}

We tend to think of climate change and adaptation to its effects as something that will take place in the (relatively distant) future. However, it is probable that climate change is already occurring and that people are already adapting to it, including by migrating from affected areas (see, eg, Warner and others 2009). Nevertheless, it remains difficult to link most contemporary climatic and associated environmental perturbations to climate change, and the likelihood is that future effects will be more 
disruptive (Parry and others 2007). Many climate-change scenarios are for 2050 and 2100 , but it is very difficult to project other environmental and social changes far into the future. Despite this, it is important to consider some of the likely implications in advance of their possible occurrence, as some planning, if not specific actions, may be more usefully implemented sooner rather than later.

While most of the discussion about climate change is future oriented, climate change is not the only environmental problem facing the region now or in the future. There are many others, some with global origins and others the result of local actions (though it is often difficult to untangle the global and the local). It is likely that these processes will interact with climate to create significant problems for future generations in PICTs. Current problems include, for example, land and coastal degradation and liquid and solid waste management. Most land degradation is related to deforestation (eg, for logging and expansion of agriculture) with implications for hydrological processes (eg, increased flood magnitude, speed of onset and sedimentation). Coastal degradation particularly relates to coral and mangrove ecosystems, which are being damaged or destroyed. These are significant ecosystems for protection from coastal events such as storm surges and sealevel rise, which are projected to increase under most climate-change scenarios. Most PICTs struggle to manage waste, much of which is imported as packaging and a significant share of which is toxic. Indeed, some writers suggest that local environmental problems, which receive relatively little attention, are at least as important as climate change, if not more so (see, eg, Connell 2003). It is likely that the processes that give rise to these problems will continue well into the current century. In a number of rural areas, logging and increased demand for agricultural land are causing land degradation-a process that will reduce community resilience if continued into the future. With island environments already under pressure to sustainably provide livelihoods for their populations, it is possible that climate-change effects may act as triggers to intensify the processes of degradation and in doing so reduce access to livelihoods in the region.

One of the factors behind the increasing significance of these problems is population growth, especially in urban areas where demand for fish is harming stocks and damaging coral reefs, demand for land is seeing mangrove areas being reclaimed, and growing numbers of people are adding to solid and liquid waste flows. At the same time, informal settlements are burgeoning in many PICTs, with many structures built with limited protection against strong winds and on unstable slopes or low-lying lands. Many 
such settlements have limited access to freshwater and other infrastructure. Such areas are liable to be highly exposed to the effects of climate change.

The Secretariat of the Pacific Community has provided projections of Pacific Island populations through to 2050 (see table 2). What these show is that the region's population may increase from an estimated Io million in mid-20I I to almost I 8 million by 2050 (SPC 20II). Most of this increase is on the inter-plate islands in the western Pacific, particularly Papua New Guinea, Solomon Islands, and Vanuatu. These countries have significant coastal populations, especially the latter two, while the two former have populated atolls as well. As already noted, the Papua New Guinea Highlands is already prone to severe drought events. In comparison, the highest projected population densities are found in all but one of the Micronesian countries (including Nauru and Kiribati), and three Polynesian countries. Among the oceanic islands, Kiribati and Nauru also exhibit relatively high projected population growth rates.

In an extensive overview of climate change and migration, Graeme Hugo identified a number of global "hot spots" where places with rapidly growing populations will be heavily exposed to the effects of climate change (2OII). He included Pacific Islands among the three main groups. However, the scale of his analysis did not enable a more detailed evaluation of population and environmental change in the region. As table 2 shows, there is considerable variation in population growth characteristics and crude population densities. Accordingly, within the region there will be a range of "spots," some of which may well be "hot" and potential sources of climate-change migrants.

\section{Linking Climate Change to Migration and Relocation}

Considerable ambiguity exists around the terms used to refer to people who may migrate as a response to climate-change effects. It is important to distinguish climate-change migrants from the more generic categories of climate migrant and environmental migrant. The latter two may include people moving as a result of climate change, but they include many other categories as well. As indicated in an earlier section, a key characteristic of climate change-related migration is that it is in response to a long-term trend or set of trends, and a return to environmental conditions similar to those that existed prior to migration is likely to be unobtainable. It is also important to distinguish between climate change-forced and climate 
Table 2. Some Indicators of PICT Demographic Futures

\begin{tabular}{|c|c|c|c|c|c|}
\hline \multirow[t]{2}{*}{ Region/Country } & \multicolumn{2}{|c|}{$\begin{array}{l}\text { Population } \\
\text { Estimates }\end{array}$} & \multirow[t]{2}{*}{$\begin{array}{c}\text { Percent } \\
\text { Population } \\
\text { Increase } \\
201 \mathrm{I}-2050\end{array}$} & \multicolumn{2}{|c|}{$\begin{array}{c}\text { Crude } \\
\text { Population } \\
\text { Density } \\
\text { (persons } / \mathrm{km}^{2} \text { ) }\end{array}$} \\
\hline & 2011 & 2050 & & 2011 & 2050 \\
\hline Melanesia & $8,797,410$ & $16,339,285$ & 86 & 16.2 & 30.1 \\
\hline Fiji Islands & 851,745 & $1,060,706$ & 25 & 46.6 & 58.0 \\
\hline New Caledonia & 252,331 & 343,175 & 36 & 13.6 & 18.5 \\
\hline Papua New Guinea & $6,888,297$ & $13,271,057$ & 93 & 14.9 & 28.7 \\
\hline Solomon Islands & 553,254 & $1,181,299$ & 114 & 18.2 & 38.8 \\
\hline Vanuatu & 251,784 & 483,048 & 92 & 20.5 & 39.3 \\
\hline Micronesia & 546,491 & 720,448 & 32 & 173.2 & 228.3 \\
\hline $\begin{array}{r}\text { Federated States } \\
\text { of Micronesia }\end{array}$ & 102,360 & 109,265 & 7 & 146.0 & 155.9 \\
\hline Guam & 192,090 & 267,820 & 39 & 355.1 & 495.0 \\
\hline Kiribati & 102,697 & 163,266 & 59 & 126.6 & 201.3 \\
\hline Marshall Islands & 54,999 & 61,217 & 11 & 303.9 & 338.2 \\
\hline Nauru & 10,185 & 16,283 & 60 & 485.0 & 775.4 \\
\hline $\begin{array}{l}\text { Northern Mariana } \\
\text { Islands }\end{array}$ & 63,517 & 80,137 & 26 & 138.9 & 175.3 \\
\hline Palau & 20,643 & 22,459 & 9 & 46.5 & 50.6 \\
\hline Polynesia & 668,404 & 825,633 & 23 & 83.7 & 103.4 \\
\hline American Sāmoa & 66,692 & 98,271 & 47 & 335.0 & 493.6 \\
\hline Cook Islands & 15,576 & 15,977 & 3 & 65.7 & 67.4 \\
\hline French Polynesia & 271,831 & 348,778 & 28 & 77.2 & 99.1 \\
\hline Niue & 1,446 & 1,283 & -11 & 5.6 & 5.0 \\
\hline Sāmoa & 183,617 & 209,740 & 14 & 62.6 & 71.5 \\
\hline Tokelau & 1,162 & 1,148 & -1 & 96.9 & 95.6 \\
\hline Tonga & 103,682 & 123,008 & 19 & 159.5 & 189.2 \\
\hline Tuvalu & 11,206 & 13,858 & 24 & 431.0 & 533.0 \\
\hline Wallis and Futuna & 13,193 & 13,570 & 3 & 92.9 & 95.6 \\
\hline Total & $10,012,305$ & $17,885,366$ & & & \\
\hline
\end{tabular}

Source of statistics: SPC $20 \mathrm{II}$; slight differences in some regional totals due to rounding. 
change-induced (or motivated) migrants. The former refers to those who have lost the land, livelihood, and/or food security of their homeland to such an extent that it is no longer habitable. The latter refers to those whose homeland has experienced effects of climate change that are partial or not severe (at least not yet) and who thus may have a choice between staying and leaving, or about who goes and who stays, with a subsequent reduction of "population pressure" at the point of origin and the generation of remittances at the destination that can help offset climate-change losses at the origin. This may be seen as "rational" climate-change adaptation. It is also important to distinguish between community relocation and migration. The former refers to cases in which settlements must be largely abandoned compared to cases in which migration is based on individual and family decision making and may include several drivers in addition to climate-change effects. Figure I links the likely effects of climate change with these two sets of climate-change migrants.

How is climate change likely to affect migration? Richard Black and his coauthors identified five groups of drivers of migration: economic, political, social, demographic, and environmental (20II). Many of these drivers are indirect, and economic, political, social, and demographic processes may significantly affect environmental drivers and vice versa. The only clearly identifiable environmental driver that might unequivocally link climate change to migration is the most extreme scenario, in which the origin becomes uninhabitable, as discussed above, and community relocation is required.

It is difficult to project with much certainty how many locations will be unable to support their populations and when such failures might occur. Nevertheless, large proportions of the populations of most PICTs live in the places described above. When a location can no longer provide the necessities of life for its inhabitants, some kind of community relocation will be necessitated. Community relocation refers to "the permanent (or long-term) movement of a community (or a significant part of it) from one location to another" (Campbell and others $2007, \mathrm{I} 2$ ). Relocation may be seen as a subset of migration, which often includes individual and small group mobility and does not necessarily require that everyone move to the same place.

Relocation may be considered the most extreme form of climate migration and is considered by many to be a last-resort adaptation option (Barnett and Webber 20I0; Barnett and O'Neill 20I2). I agree with such an approach but caution that communities' moving from areas prone to 


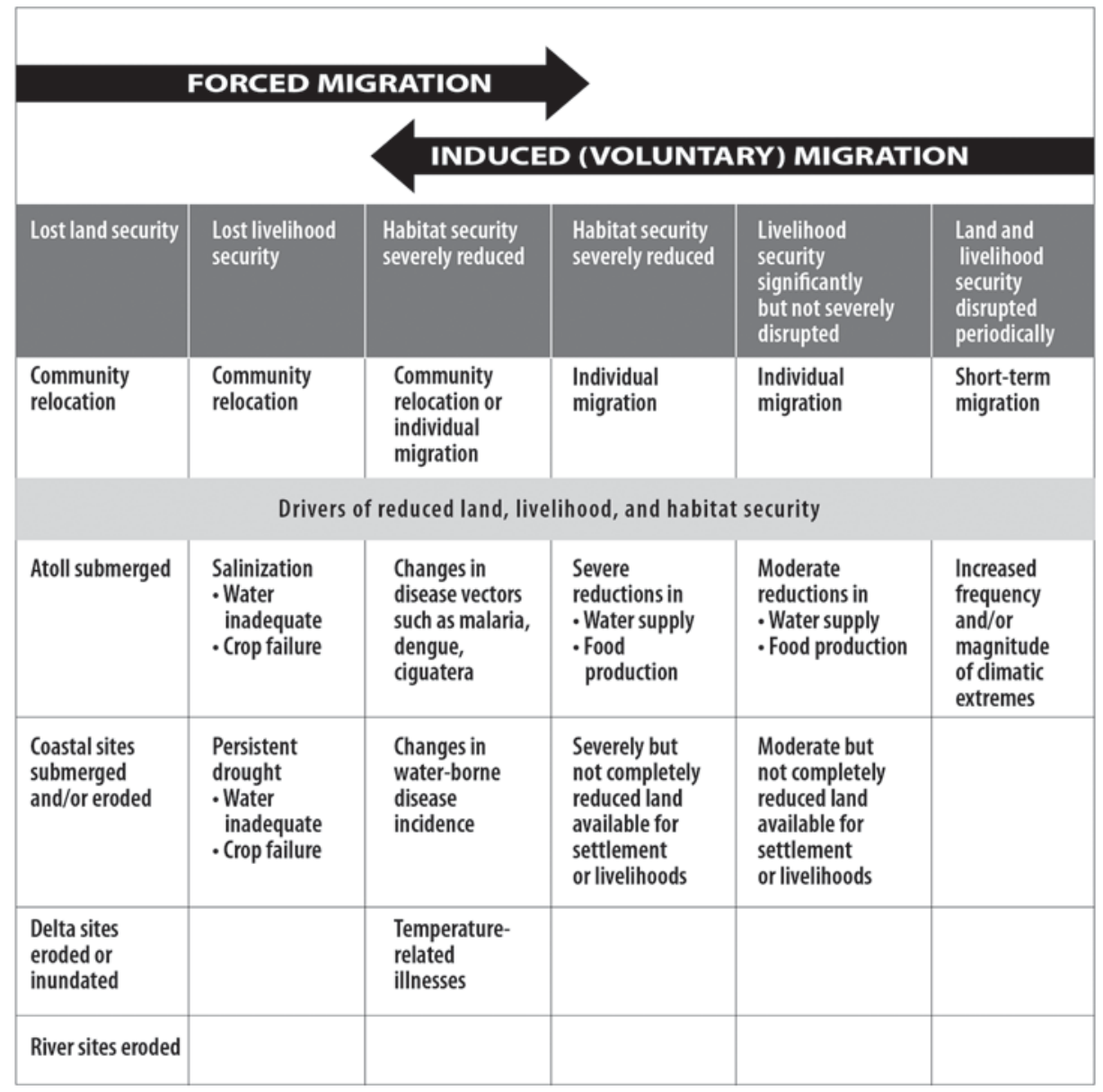

FIGURE I. Forced and induced migration in the context of climate-change effects on land, livelihood, and/or habitat security (after Campbell and Bedford 2013).

natural extremes is a well-used disaster risk reduction response, and it has been practiced throughout the Pacific region for a long time (Campbell and others 2007). Additionally, if communities are repeatedly subjected to losses from extreme events, a stoic in situ approach—staying put-may well be ill advised, or even immoral, if promoted by authorities (eg, by their not providing adaptation funding for relocation) or by the international community, especially greenhouse gas emitters (by their not providing migration access). Furthermore, climate change presents a new set of circumstances for all types of migrants: what is the point of returning to 
an environment that is likely to fail to provide "life support" on an ever more frequent basis?

\section{Where Will Climate-Change Migrants Come From?}

As stated above, there are several possible source areas for climate-change migration in addition to atolls, which are the focus of popular perceptions. For example, there may also be larger flows of people from inland places on inter-plate islands exposed to more frequent or increasingly damaging droughts: the Papua New Guinea Highlands alone boasts a population much greater than that of the rest of the Pacific combined (not including Papua New Guinea). Nevertheless, it is also likely that many climatechange migrants, including community relocatees, may come from atolls, coastal and delta settlements, and river floodplains, where land, livelihood, and habitat security is degraded or destroyed. Generally speaking, the migrants from delta and river floodplain settlements are most likely to originate from Melanesia, where the large inter-plate type islands have well-developed hydrological systems. Because atolls have little land that lies significantly above sea level, it is possible that entire islands may be rendered uninhabitable. It is difficult to estimate the current populations of these different types of exposed areas, let alone project them. According to J C Pernetta (1990), there are 204 atolls in the Pacific Islands region, though not all are populated. As table 3 shows, these are found in four political units that consist solely of atolls as well as in at least nine other PICTs that have both populated atolls and high islands. The atoll-only countries may have populations of around 240,000 by mid-twenty-first century (40 percent greater than their current populations). It is much more difficult to establish projections for the atolls that are only part of larger countries, but if we applied the respective national growth rates to them (which is problematic), we might expect the populations of these atolls to increase from an estimated 55,000 to around 80,000 people (an increase of 45 percent over the next forty years or so). Combined, this yields a projected total atoll population for the region of around 320,000 people. It is important, however, not to assume that all of the atoll dwellers are likely to be forced to migrate: effects may differ from place to place, as will the implementation of in situ adaptation measures.

While it is difficult to estimate the number of potential environmental migrants from non-atoll locations, it is likely that the numbers affected by climate change will be significant, and forced, induced, or voluntary cli- 
Table 3. гіст Atoll Population Estimates and Projections

\begin{tabular}{|c|c|c|c|}
\hline \multicolumn{3}{|c|}{ Atoll Only PICTs } & High Island Countries with Atolls \\
\hline & \multicolumn{2}{|c|}{ Population Estimates ${ }^{a}$} & \\
\hline & 2011 & 2050 & $\begin{array}{l}\text { Papua New Guinea } \\
\text { Solomon Islands }\end{array}$ \\
\hline Kiribatib & 102,697 & 163,266 & New Caledonia \\
\hline Marshall Islands & 54,999 & 61,217 & Federated States of Micronesia \\
\hline Tokelau & 1,162 & 1,148 & Palau \\
\hline Tuvalu & 11,206 & 13,858 & $\begin{array}{l}\text { American Sāmoa } \\
\text { Tonga }\end{array}$ \\
\hline Totals & 170,064 & 239,489 & $\begin{array}{l}\text { Cook Islands } \\
\text { French Polynesia }\end{array}$ \\
\hline & & & $\begin{array}{l}\text { Total Population Estimates 2009: c 55,000 } \\
\text { Total Population Estimates 2050: c } 80,000^{c}\end{array}$ \\
\hline
\end{tabular}

a Source: SPC 201 I.

${ }^{b}$ Kiribati includes one raised limestone island, Banaba, the population of which was relocated to Rabi in Fiji after the Second World War. A small caretaker population of Banabans remains on the island.

c Source: Campbell 20 I.

mate migration from these areas may be an important response to climate change and could involve greater numbers of people than those from the atolls.

\section{Where Will Climate-Change Migrants Go?}

Most studies of relocation or resettlement tend to focus on the experiences of the migrants rather than those of the people who stay behind. An important early publication is Exiles and Migrants in Oceania (Lieber I977). The ten case studies presented in this volume, only one of which examines relocation to nearby lands, indicate that relocated communities often face difficulties at their destinations. This is especially so where the 
relocation is to places with a different dominant culture from the island or village of origin, leading to tensions between migrant and host communities (see, eg, Carroll 1977). Research on the likelihood that climate change may affect patterns of mobility including community relocation in the Pacific region is relatively recent. Most work has focused on legal issues, human rights, and policy considerations relating to climate changeforced migrants (Burson 20I0; McAdam 20I0). From the perspective of those who remain behind, Jon Barnett, using Niue as an example, showed that while climate-induced migration may be seen as a useful adaptive mechanism, where populations at the origin become too small, the migration may have several negative implications for the community of origin (2OI2).

The range of destination options available for climate-change migrants and relocatees depends on a number of factors, including the availability of destinations at their disposal. Figure 2 and table 4 show the range of migration possibilities for those affected by climate change. In the case of community relocation, there are likely to be numerous barriers and costs, for example, rebuilding houses and schools, even when the move is within customary lands. Moving across customary boundaries and farther beyond to crossing international borders increases the costs. Indeed, it is difficult to imagine the complete relocation of a Pacific Island community to a place outside the Pacific region where new laws are likely to conflict with traditional lore (eg, fishing laws, building codes, and systems of political authority); where suitable land may be rare and/or exceedingly expensive; and where destination community support may be lacking. Many may choose, at least initially, to stay close to their customary lands or at least within their country (in either case if such options are possible). For others, however, international migration or relocation may be a more optimal choice and, in the cases of some atoll countries, conceivably a sole response option. Figure 2 indicates some of the implications of various forms of community relocation. A key element in Pacific Island settings is the role of customary land, which in most parts of the region is inalienable and can only "belong" to the people who "belong" to it. For relocatees, to be forced from one's land is likely to be highly traumatic, but the giving up of land to relocatees by destination communities may be equally difficult (Campbell 2010a). Proximate relocation outside one's customary land, or relocation to other PICTs, is likely to be fraught with problems over land tenure, which can continue for generations. Issues of land and climate change have been relatively neglected in the literature, as have the emo- 


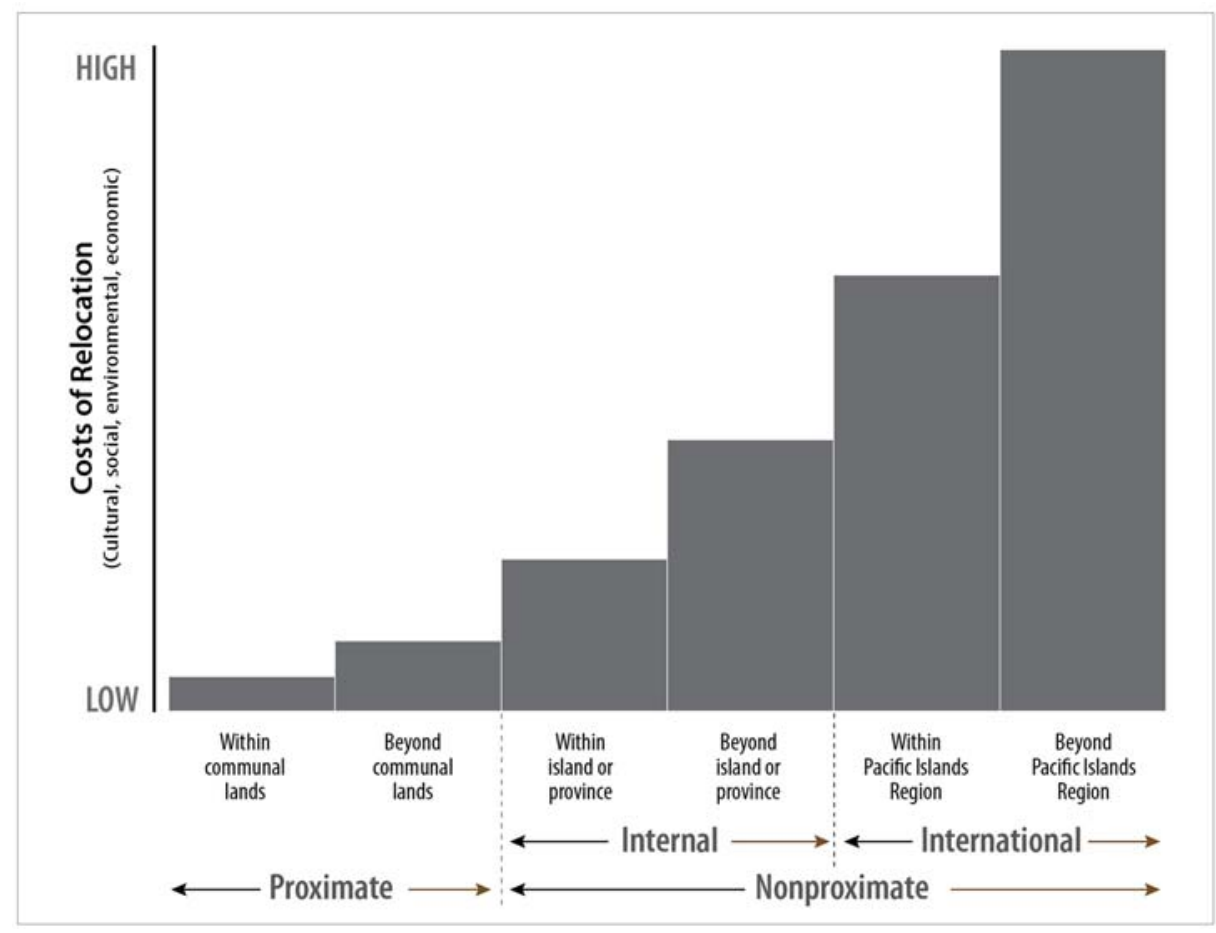

FIGURE 2. Migration and relocation options for climate change induced or forced migrants and relocatees (after Campbell 2orob).

Table 4. Types of Climate-Change Migration from ріст Origins

Type of Mobility

Induced $\quad$ Forced

Migration

Individuals and

Communities relocate

families migrate

\section{Domestic/Internal}

Proximate (own lands)

Proximate (others' lands)

Not likely

Least disruptive

Distant (rural $\rightarrow$ rural)

Not likely

Land can be problematic

Distant (rural $\rightarrow$ urban)

Not likely

Land likely to be problematic

Most likely

Difficult to sustain community

\section{International/External}

Regional (other PICTs)

Possible

Possible to sustain community and lifestyle but land problematic

International

Most likely

Very unlikely to sustain community and lifestyle 
tional aspects for those exposed to climate change and forced to migrate (see, eg, Stratford and others 2013).

\section{Domestic Migration and Community Relocation}

As table 4 shows, there are four main possibilities for domestic or internal relocation: to move inland and up to nearby locations within the individuals' or communities' customary lands; to move to nearby locations that are outside the individuals' or communities' customary lands; and to move greater distances (either within one's own island or province or farther afield) away from the local area to lands that belong to other customary groups. The last option is most likely to include migration to informal settlements in urban areas, but other forms of rural-torural mobility may also take place (eg, from Carteret Islands, which are experiencing heavy coastal erosion, in Papua New Guinea, to nearby Bougainville). All forms of migration have costs, but these increase with physical and social (particularly from a customary perspective) distance from the origin, and these costs are likely to be even higher when whole communities are required to relocate (figure 2). The least problematic form of relocation is to locations within one's own customary territory, as in the case of the community on the Biausevu River, inland from the Coral Coast on Viti Levu, which is prone to flash flooding during tropical cyclones and heavy rainfall events. This community moved four times over one hundred years before moving upward to a site on a nearby hilltop (Campbell and others 2007). All of the moves were within customary lands. Now, however, there is no longer available space on the hilltop, and new houses are being built once again near the river. As noted above, relocating to land belonging to a different kinship group (whether within one's own country or even in another PICT) is often fraught with longstanding tensions (Campbell 2oroa). For example, Bedford outlined the tensions between mataqali (clans) from two villages on the island of Kabara in eastern Fiji that were intensified by the government-initiated relocation of a village following a destructive cyclone four decades earlier in 1936 (Bedford 1976). Despite several attempts over decades, Carteret Island people are still struggling to find sufficient land to resettle in Bougainville (Campbell 20Iоa). From a practical perspective, Vinau Cagilaba compared two Fijian villages that had been inundated by several storm surge events (2005). One of the villages remained on site and raised money to build a seawall, while the other moved upslope and away from the coast. Both communities found disadvantages as a result 
of their choices: the one that built the seawall had to constantly raise funds and work to maintain their coastal protection, and the upslope people, particularly the women, found the task of carrying water uphill onerous. Both responses were seen as permanent; as one villager put it, it was "a life sentence."

\section{International Migration and Community Relocation}

Table 5 shows possible international forms of climate-change migration. Where international migration pathways are available, many climatechange migrants may choose such an option. The closest options are island states within the region. There are three precedents: from Banaba (in the Gilbert Islands) to Rabi (in Fiji) (Silverman I97I, I977; Teaiwa 2005); from Vaitupu (in the Ellis Islands) to Kioa (in Fiji) (Koch I978); and from the Gilbert Islands to Western Province (in Solomon Islands) (Knudson I977). However, it is informative to recall that all three examples (none of which was without problems, including the issue of land) took place during the colonial era and were basically enabled (or encouraged) by the British colonial system in the form of the Fiji and Western Pacific high commissions (Campbell 20IOa). However, from a contemporary perspec-

Table 5. The Range of Possible Destinations for PICт Climate-Change Migrants and Relocatees

Possible groups of destination countries for climate change forced or induced international relocation or migration

Other PICTS

Current colonial countries and administrations

Freely associated countries

Previous colonial countries and administrations (at time of independence)

Pacific Rim countries (not included above)

Any other takers
Countries included in destination groups

All PICTs with secure land (environmental, cultural)

France, New Zealand, United States

New Zealand, United States

Australia, France, New Zealand, United Kingdom, United States

East Asian, North American, Central American, and South American countries The rest of the world? 
tive it is doubtful that existing Pacific Island sovereign states will enable such easy entry and settlement.

Looking farther afield, there are no examples of community relocation to countries outside of the Pacific region, although the New Zealand government began a resettlement scheme, including assisted migration, for people from Tokelau, which it considered to be overpopulated and which in I966 suffered the effects of a major tropical cyclone (Huntsman and Hooper 1973; Wessen and others I992). By the time of the 2006 census in New Zealand, there were almost five times as many Tokelauans living in New Zealand as in Tokelau itself. As with Tokelauans, a number of

Table 6. PICTs with International Migration Access

\begin{tabular}{ll}
\hline PICT of Origin & Country of Destination ${ }^{a}$ \\
\hline $\begin{array}{l}\text { American Sāmoa } \\
\text { Federated States of Micronesia }\end{array}$ & United States \\
Guam & \\
Marshall Islands & \\
Northern Mariana Islands & \\
Palau & New Zealand ${ }^{\mathrm{b}}$ \\
Cook Islands & \\
Niue & \\
Sāmoa & \\
Tokelau & France \\
French Polynesia & \\
New Caledonia & \\
Wallis and Futuna & \\
\hline
\end{tabular}

ancludes countries with formal access or with large populations from PICTs listed in column $\mathrm{I}$.

${ }^{b}$ Small numbers are able to enter New Zealand from Kiribati (75), Tonga (250), and Tuvalu (75) annually. In addition, New Zealand allows up to 8,000 temporary horticultural workers from Vanuatu, Tonga, Sämoa, Solomon Islands, Tuvalu, and Kiribati to participate under the Recognised Seasonal Employer policy (Bedford and Hugo 20I 2). 


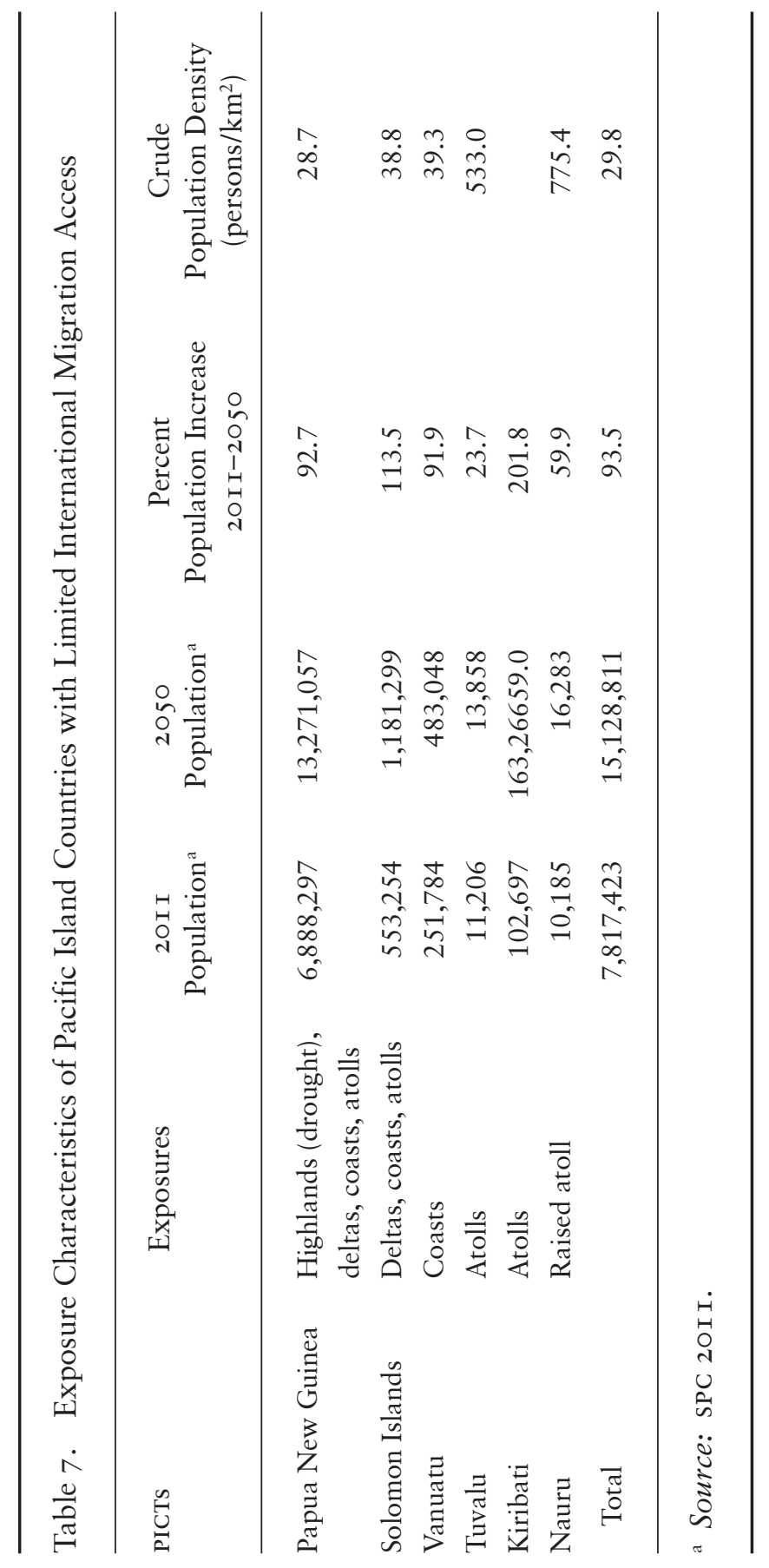


migrants from several PICTs have access to France, New Zealand, and the United States through existing colonial linkages or because their country is self-governing in free association with one of these metropolitan countries. These are shown in table 6. For example, Tokelau, Niue, and the Cook Islands are linked to New Zealand through their territorial or free association status, and Tonga, Fiji, and Sāmoa have large populations living in New Zealand. Similarly, the French territories are considered to be parts of France, and migration between French territories in the Pacific may also be affected by climate change, most likely with increased flows to New Caledonia. Some may also migrate farther to France itself. Likewise, the Micronesian countries and territories (with the exception of Kiribati and Nauru) have access to the United States, although there have been recent calls to place restrictions on some of these flows.

However, as table 7 indicates, there is a group of countries with very limited opportunities for international migration access. The table also shows that most of these countries have high levels of exposure to climate-change effects and either high rates of population growth rates or high crude population densities, or both. This group of countries includes Papua New Guinea, Solomon Islands, and Vanuatu, all on inter-plate islands (which are also characterized by high population growth rates, river floodplains and deltas in particular, and coastal settlements and drought-prone places); the two atoll states of Tuvalu and Kiribati (which have very high population densities and are exposed to loss of land, livelihood, and habitat security); and the raised atoll Nauru (also with a high population density and limited livelihood options). They may well fall, in the future, into the group of countries with the greatest need for induced and forced international migration options but with the fewest choices. A major issue for increased international migration as a climate-change adaptation, therefore, is likely to be one of migration access.

\section{Conclusions}

This paper has canvassed some of the key issues relating to climate change and migration in PICTs. It has identified two main categories of climatechange mobility. The first, climate change-induced migration, is difficult to distinguish from existing migration patterns, and the climate-change motivations or drivers of migration decision making are similarly difficult to distinguish from other economic, social, political, demographic, and other environmental influences (which are closely interrelated). Neverthe- 
less, climate-change effects may cause reductions in the land, livelihood, and habitat security of Pacific Island communities, which makes sustained occupation by all members marginal. From this perspective, reducing numbers and supplementing the declining island life-support system through remittances is an appropriate adaptation option.

The second form of climate-change mobility is forced relocation, in which the land, livelihood, and habitat security have been so compromised by climate-change effects that sustained habitation is rendered impossible. Community relocation following repeated natural extreme events is not rare in the region and is likely to become a necessity for some communities faced with climate change, although it is difficult to identify just when such need will arise. Nevertheless, it seems illogical to expect village communities to endure increases in drought and flood frequencies and magnitudes and tropical cyclones of increasing intensity and to continue to rebuild houses and other buildings and rehabilitate agriculture and water supply systems until it is affirmed that their land is definitely no longer suitable for habitation. More appropriate will be a proactive approach to migration and relocation that will enable communities and their individual members to be well prepared if voluntary migration or forced relocation is necessary. This may entail considerable dialogue between governments as well as between local communities at the places of origin and destination.

At the beginning of this article, I observed that PICTs contribute very little to the climate-change problem but are among those most likely to be adversely affected. From this perspective, it would seem appropriate that they should be compensated by greenhouse gas emitters, especially those who do not reduce their emissions, for the costs they incur in their efforts to adapt to changes they have not caused. As migration is an adaptation option, the costs of migration (and community relocation in particular) should be covered by such bodies as the Adaptation Fund Board. Such costs may include contribution to airfares, the purchase of land for resettlement schemes, and the building or purchase of homes.

As this article shows, some of the greatest demand for migration responses to climate change may come from countries without full access to Pacific Rim or former colonial countries. In addition, flows along existing migration pathways may increase. Signatories to the United Nations Framework Convention on Climate Change are committed to helping those communities most at risk from the effects of climate change. It would seem, however, that enabling adaptation to climate change by 
allowing or facilitating increased mobility is likely to be a major challenge for the international community.

I WOULD LIKE TO THANK the reviewers, whose responses and suggestions proved invaluable, and all those friends and colleagues with whom I have discussed these issues over the years.

\section{Notes}

I The report of Working Group I of the IPCC's fifth assessment has been released (IPCC 20I3). This report indicates greater certainty among physical scientists of the existence of anthropogenic climate change. The Working Group II report, which includes a chapter on small islands, is scheduled for release in the first half of 2014.

2 These terms have become dominant in the context of climate change. Mitigation causes confusion in the area of disaster risk reduction, which is becoming increasingly connected to adaptation. Adaptation, drawn from biology, may be seen as problematic from a social science perspective because it seems to suggest that humans have little agency. However, the contemporary literature on such topics as community-based adaptation focuses on empowering communities, rather than representing them as passively being forced to adapt or adjust.

3 The IPCC AR4 Working Group II (Parry and others 2007) defines adaptation as follows: adjustment in natural or human systems in response to actual or expected climatic stimuli or their effects, which moderates harm or exploits beneficial opportunities.

\section{References}

AвM and Csiro, Australian Bureau of Meteorology and Commonwealth Scientific and Industrial Research Organisation

20 I Climate Change in the Pacific: Scientific Assessment and New Research, vol I: Regional Overview. Aspendale, vic: Pacific Climate Change Science Program.

Barnett, Jon

20 I2 On the Risks of Engineering Mobility to Reduce Vulnerability to Climate Change: Insights from a Small Island State. In Climate Change and Human Mobility: Global Challenges to the Social Sciences, edited by Kirsten Hastrup and Karen Fog Olwig, I69-I89. Cambridge, UK: Cambridge University Press. 
Barnett, Jon, and John R Campbell

2010 Climate Change and Small Island States: Power, Knowledge, and the South Pacific. London: Earthscan.

Barnett, Jon, and Natasha Chamberlain

20I0 Migration as Climate Change Adaptation: Implications for the Pacific. In Climate Change and Migration in the South Pacific Region: Policy Perspectives, edited by Bruce Burson, 5I-60. Wellington: Institute of Policy Studies.

Barnett, Jon, and Saffron J O’Neill

2012 Islands, Resettlement and Adaptation. Nature Climate Change 2 (I): 8 -IO.

Barnett, Jon, and Michael Webber

2010 Accommodating Migration to Promote Adaptation to Climate Change. Policy Research Working Paper 5270, April. Washington, DC: World Bank.

Bayliss-Smith, Tim, Richard Bedford, Harold Brookfield, and Marc Latham I988 Islands, Islanders and the World: The Colonial and Post-colonial Experience of Fiji. Cambridge, uk: Cambridge University Press.

Bedford, Richard

I976 Kabara in the I970s: Dimensions of Dependence in a Contemporary Lauan Society. Unesco/unfPa Project on Population and Environment in the Eastern Islands of Fiji Working Paper 3. Canberra: Development Studies Center, the Australian National University.

Bedford, Richard, and Graeme Hugo

2012 Population Movement in the Pacific: A Perspective on Future Prospects. Wellington: Department of Labour.

Black, Richard, W Neil Adger, Nigel W Arnell, Stefan Dercon, Andrew Geddes, and David Thomas

20I I The Effect of Environmental Change on Human Migration. Global Environmental Change 2I (s): S3-SII.

Brown, Oli

2008 Migration and Climate Change. IOM Migration Research Series 3I. Geneva: International Organization for Migration. http:// publications.iom.int/bookstore/free/MRS-3 I_EN.pdf

Burson, Bruce, editor

2010 Climate Change and Migration in the South Pacific Region: Policy

Cagilaba, Vinau Perspectives. Wellington: Institute of Policy Studies.

2005 Fight or Flight? Resilience and Vulnerability in Rural Fiji. Master's of social science thesis, University of Waikato, Hamilton, New Zealand. 
Campbell, John R

20roa Climate-Induced Community Relocation in the Pacific: The Meaning and Importance of Land. In Climate Change and Displacement: Multidisciplinary Perspectives, edited by Jane McAdam, 57-79. Oxford: Hart Publishing.

20Iob Climate Change and Population Movement in Pacific Island Countries. In Climate Change and Migration in the South Pacific Region: Policy Perspectives, edited by Bruce Burson, 29-50. Wellington: Institute of Policy Studies.

20I I Climate Change and Population Displacement. In Population and Development in the Pacific Islands, edited by Wadan Narsey, 32034I. Suva: UNFPA and the School of Economics, University of the South Pacific.

Campbell, John R, and Richard Bedford

20I3 Migration and Climate Change in Oceania. In People on the Move in a Changing Climate: The Regional Impact of Environmental Change on Migration, edited by Etienne Piguet and Frank Lazco, I 77-204. Dordrecht: Springer.

Campbell, John R, Michael Goldsmith, and Kanyathu Koshy

2007 Community Relocation as an Option for Adaptation to the Effects of Climate Change and Climate Variability in Pacific Island Countries (PICS). Final report for APN project 2005-I4-NSY-Campbell. Tokyo: Asia-Pacific Network for Global Change Research.

Carroll, Vern

I977 Communities and Noncommunities: The Nukuoro on Ponape. In Lieber $1977,67-79$.

Christian Aid

2007 Human Tide: The Real Migration Crisis. London: Christian Aid. http://www.christianaid.org.uk/images/human-tide.pdf [accessed I3 Sept 20I3]

Connell, John

2003 Losing Ground? Tuvalu, the Greenhouse Effect and the Garbage Can. Asia Pacific Viewpoint 44 (2): 89-107.

Fiji Forestry Department

2OI I Fiji REDD-Plus Policy: Reducing Emissions from Deforestation and Forest Degradation in Fiji. Suva: Government of Fiji, Ministry of Primary Industries.

Hooper, Antony, and Judith Huntsman

I973 A Demographic History of the Tokelau Islands. Journal of the Polynesian Society 82 (4): 366-4 I I. 
Hugo, Graeme

20II Future Demographic Change and Its Interactions with Migration and Climate Change. Global Environmental Change 2I (s): S2 I-s33. IPCC, Intergovernmental Panel on Climate Change

2013 Climate Change 2013: The Physical Science Basis. Working Group I Contribution to the IPCC Fifth Assessment Report (AR 5). Geneva: IPCC Secretariat. http://www.ipcc.ch/index.htm\#.Um_kYxapNoM [accessed 29 Oct 2013]

Lieber, Michael D, editor

I977 Exiles and Migrants in Oceania. AsAo Monograph 5. Honolulu: The University Press of Hawaii.

Knudson, Kenneth E

I977 Sydney Island, Titiana, and Kamaleai: Southern Gilbertese in the Phoenix and Solomon Islands. In Lieber I977, I95-24I.

Koch, Klaus-Friedrich

I978 Logs in the Current of the Sea. Canberra: Australian National University Press.

McAdam, Jane, editor

20 Iо Climate Change and Displacement: Multidisciplinary Perspectives. Oxford: Hart Publishing.

Mimura, N, L Nurse, R F McLean, J Agard, L Briguglio, P Lefale, R Payet, and G Sem

2007 Small Islands. In Parry and others 2007, 687-716.

Morton, Adam

2009 First Climate Refugees Start Move to New Island Home. The Age [Melbourne], 29 July. http://www.theage.com.au/national/first -climate-refugees-start-move-to-new-island-home-20090728-eo6x .html

Myers, Norman

2005 Environmental Refugees: An Emergent Security Issue. Paper given at the 13 th Economic Forum of the Organization for Security and Cooperation in Europe (OSCE), Prague, 23-27 May. http://www.osce .org/eea/I 485 I

Parry, M L, O F Canziani, J P Palutikof, P J van der Linden, and C E Hanson, editors

2007 Climate Change 2007: Impacts, Adaptation and Vulnerability. Contribution of Working Group II to the Fourth Assessment Report of the Intergovernmental Panel on Climate Change. Cambridge, uK: Cambridge University Press.

Pernetta, J C

I990 Projected Climate Change and Sea Level Rise: A Relative Impact 
Rating for the Countries of the Pacific Basin. In Implications of Expected Climate Changes in the South Pacific Region: An Overview, edited by J C Pernetta and P J Hughes, I4-24. UNEP Regional Seas Reports and Studies I 28. Nairobi: United Nations Environment Programme.

SPC, Secretariat of the Pacific Community

20I0 Towards an Energy Secure Pacific: A Framework for Action on Energy Security in the Pacific. I7 June. Noumea: SPC. Available on the SPREP website: http://www.sprep.org/att/irc/ecopies/pacific _region/686.pdf

20I I Pacific Island Populations-Estimates and Projections of Demographic Indicators for Selected Years. Noumea: SPC.

SPREP, Secretariat of the Pacific Regional Environment Programme

201220 I I Annual Report of the Secretariat of the Pacific Regional Environment Programme. Apia: SPREP.

Silverman, Martin G

I97I Disconcerting Issue: Meaning and Struggle in a Resettled Pacific Community. Chicago: University of Chicago Press.

I977 Making Sense: A Study of a Banaban Meeting. In Lieber I977, I 2 II 60 .

Stratford, Elaine, Carol Farbotko, and Heather Lazrus

20I3 Tuvalu, Sovereignty and Climate Change: Considering Fenua, the Archipelago and Emigration. Island Studies Journal 8 (I): 67-83.

Tacoli, C

2009 Crisis or Adaptation? Migration and Climate Change in a Context of High Mobility. Environment and Urbanization 2I (2): 5I3-525.

Teaiwa, Katerina Martina

2005 Our Sea of Phosphate: The Diaspora of Ocean Island. In Indigenous

Diasporas and Dislocations, edited by Graham Harvey and Charles

D Thompson Jr, I69-I92. Aldershot, UK: Ashgate.

Warner, Koko, Charles Ehrhart, Alex de Sherbinin, Susana Adamao, and Tricia Chai-Onn

2009 In Search of Shelter: Mapping the Effects of Climate Change on Human Migration and Displacement. Cooperative for Assistance and Relief Everywhere (CARE). http://www.ciesin.columbia.edu/ documents/clim-migr-report-juneo9_media.pdf

Wessen, Albert F (editor), Antony Hooper, Judith Huntsman, Ian A M Prior, and Clare E Salmond

I992 Migration and Health in a Small Society: The Case of Tokelau. Research Monographs on Human Population Biology 8. Oxford: Clarendon Press. 


\section{Abstract}

Despite considerable debate about whether or not climate change will cause large numbers of people to migrate, there has been little consideration of how such displacement might be caused. Three effects of climate change are identified as possible drivers of migration: loss of or reduction in land security, livelihood security, and habitat security. Where these are destroyed by climate change, migration will be forced and would require the abandonment of some locations. Such community relocation is likely to be a disruptive form of climate-change migration, and past experience indicates that there are numerous social, cultural, emotional, and economic costs associated with such moves, even at relatively small distances. Where the loss of security is partial, voluntary or induced migration may be a practical adaptive response, reducing pressure on declining local life-support systems and providing remittances to supplement declining livelihoods. Most attention has been focused on atoll communities, but most Pacific communities (with the exception of Papua New Guinea) are coastal, and the security of some inland areas may be threatened by increasing magnitude and frequency of droughts. Destinations for climate-change migrants may range from locations within customary lands to foreign countries within and beyond the region. A key issue is the essential link between Pacific Islands people and their land, which poses major problems not only for those forced to leave but also for communities within the region that may be required to give up land for relocatees.

KEYWORDS: climate change, migration, relocation, land security, livelihood security, habitat security 